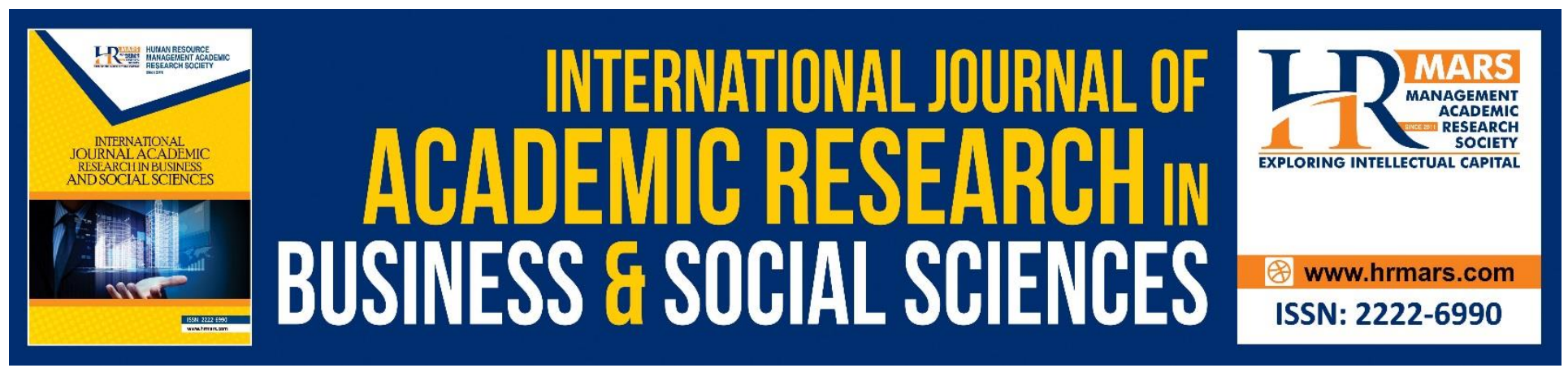

\title{
Competency of Teachers in Teaching Practical Implementation of Subject Furniture Manufacturing for Malaysian Skills Certification Program
}

Mohd Zaini Osman, Che Ghani Che Kob, Sharifah Shahida Syed Abdullah

To Link this Article: http://dx.doi.org/10.6007/IJARBSS/v9-i5/5841

DOI: $10.6007 /$ IJARBSS/v9-i5/5841

Received: 02 March 2019, Revised: 20 March 2019, Accepted: 15 April 2019

Published Online: 03 May 2019

In-Text Citation: (Osman, Kob, \& Abdullah, 2019)

To Cite this Article: Osman, M. Z., Kob, C. G. C., \& Abdullah, S. S. S. (2019). Competency of Teachers in Teaching Practical Implementation of Subject Furniture Manufacturing for Malaysian Skills Certification Program. International Journal of Academic Research Business and Social Sciences, 9(5), 78-89.

Copyright: (C) 2019 The Author(s)

Published by Human Resource Management Academic Research Society (www.hrmars.com)

This article is published under the Creative Commons Attribution (CC BY 4.0) license. Anyone may reproduce, distribute, translate and create derivative works of this article (for both commercial and non-commercial purposes), subject to full attribution to the original publication and authors. The full terms of this license may be seen at: http://creativecommons.org/licences/by/4.0/legalcode

\section{Vol. 9, No. 5, 2019, Pg. 78 - 89}

Full Terms \& Conditions of access and use can be found at http://hrmars.com/index.php/pages/detail/publication-ethics 


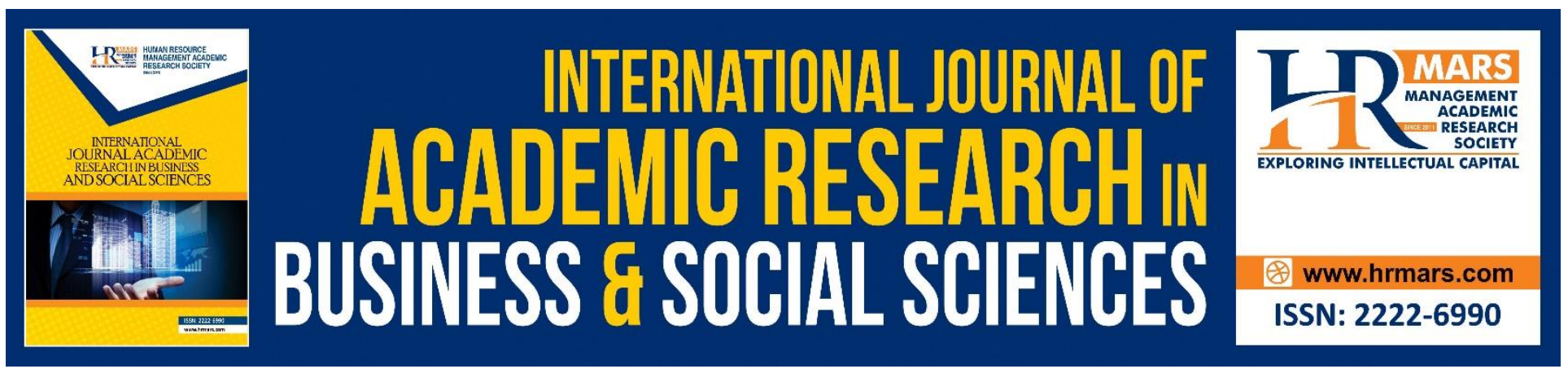

\title{
Competency of Teachers in Teaching Practical Implementation of Subject Furniture Manufacturing for Malaysian Skills Certification Program
}

\author{
Mohd Zaini Osman, Che Ghani Che Kob, \\ Sharifah Shahida Syed Abdullah \\ Faculty of Technic and Vocational, Universiti Pendidikan Sultan Idris, \\ 35900 Tanjung Malim, Perak, Malaysia
}

\begin{abstract}
Changes in the technical and vocational education system are seen as demanding and require teachers who are truly competent to engage in teaching and learning including practical at the workshop. Teachers who fulfill the competence components will certainly be able to perform their duties and responsibilities well and excel. This is to ensure the teachers can produce human capital who really have high skills and knowledge to meet the needs of the job market in the relevant industry. This paper discusses three elements of teacher's competency in the teaching of Furniture Manufacturing Practices (FMP) for the Malaysia Skills Certificate (MSC) which are excellent skill, knowledge and attitude. In addition, teachers' competence issues in FMP teaching are also being addressed. The Iceberg Competency Model is used as a reference to determine the characteristics and level of competency of FMP practitioners. This discussion is based on relevant sources of scientific references and past studies.

Keywords: Teachers' competence, Furniture Manufacturing Practice, Malaysian Skill Certificate, Technical and Vocational Education.

\section{Introduction}

Competence refers to the knowledge, skills and attitudes or personal values needed to perform a task and responsibility in accordance with specifications and requirement (Siraj \& Ibrahim, 2012). In addition, competence also means "profiency competence, skillful and skill" (Daud, 2003). These three components or elements that are often dealt with by researchers to describe the characteristics of competencies that must be owned by the person who assumed the duties of teachers.
\end{abstract}


A teacher who meets the competency course will carry out duties and responsibilities of the position held with dedication, effort and earnest without characterized as described in the Malay proverb, "like a chisel with a hammer". This can be seen by the evidence shown the improved performance in carrying out their duties at all times. The level of competence of teachers internship Furniture Manufacturing Practices (FMP) effort means the ability of teachers to deliver lesson content involving major component of competence that is knowledgeable in the area of skills involved, skilled explaining and demonstrating and displaying a good attitude and determination in dealing with teaching practice FMP in the workshop. This includes things before, during and after the practical sessions FMP executed.

Teachers who meet the competence indispensable component in FMP lessons because the teacher is certainly able to deliver hands-on science and attract students to participate in hands-on teaching sessions that have been planned. The situation is very important because it will be able to unearth the latent skills in students. Additionally, it will reduce student participation in unhealthy activities such as skipping classes and truancy because they are not interested in academic subjects that are required for them to follow him (Cachia, Ferrari \& Ala-Mutka, 2010). In conclusion, highly competent teachers will certainly be able to produce skilled human capital, knowledge and attitudes that are superior and competitive at the global level in the field of vocational education.

\section{Concept of Teacher Competency}

Other terms for competence are generic skills, basic skills, key skills and personal skills that pertain to the knowledge, skills and attitudes that form the basis of a task or work performance across all areas of responsibility (Rylatt, \& Lohan, 1995). Competence is also a combination of knowledge, ability and experience that allows individuals to perform a task perfectly. The ability of a person to show a system that is related to the function in achieving performance goals also known as competencies (Boyatzis, 1982). The term competence is often called as a group of related knowledge skills and attitudes that affect one's duties, closely related to job performance and measured in accordance with certain standards.

The three main things that need to be considered in determining the learning outcomes to be achieved by students are knowledge (cognitive), skills (psychomotor domain) and attitude (affective domain). Indirectly, the competencies achieved and acquired by a group of students also reflect the level of competence of teachers who teach them. The components contain in an assessment of competence are knowledge, attitudes and skills (Carraciao, \& Englander, 2004). This theory is also supported by the state Bloom's Taxonomy competencies that are categorized in three groups: cognitive, affective domain and psychomotor domain (Bloom, 1956). Iceberg's model said knowledge and skills developed and more easily identified than personality attitude which is difficult to be identified, modified and molded (Mestry, \& Grobler, 2004). However, the attitude of personality is the most important factor and should be taken into account before determining the level of competence of a teacher than having the knowledge and skills needed in options education.

Based on the definition and Competency Model "Iceberg", it can be concluded that teacher competence in teaching practice is a combination of knowledge, skills and attitudes in carrying out the practice of teaching practice effectively. The concept paper refers to all three of these components as teacher competence that affect practice practical lessons during the workshop 
INTERNATIONAL JOURNAL OF ACADEMIC RESEARCH IN BUSINESS AND SOCIAL SCIENCES Vol. 9, No. 5, May, 2019, E-ISSN: 2222-6990 @ 2019 HRMARS

\section{Elements of Competency}

Table 1 Elements of Competency According to A Few Studies Ago

\begin{tabular}{|c|c|c|c|c|c|c|c|c|c|c|c|}
\hline Research & A & B & C & D & $\mathbf{E}$ & $\mathbf{F}$ & G & H & I & J & \multirow{3}{*}{$\begin{array}{l}\text { Hint: } \\
\text { A Knowledge } \\
\text { B Skills }\end{array}$} \\
\hline Zaiha Nabila (2014) & $\mathrm{V}$ & V & $\sqrt{ }$ & & & & & & & & \\
\hline Saedah Siraj (2012) & 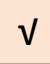 & v & 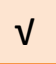 & & & & & & & & \\
\hline Azizi \& Fadhlina (2010) & v & V & 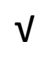 & & & & & & & & Practice \\
\hline $\begin{array}{l}\text { Sinnott, Madison dan Pataki } \\
(2002)\end{array}$ & V & & & & & & & & $\sqrt{ }$ & $\checkmark$ & D Motive \\
\hline $\begin{array}{l}\text { Treasury Board of Canada } \\
\text { (1999) }\end{array}$ & 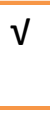 & $\mathrm{V}$ & $\sqrt{ }$ & & $\mathrm{V}$ & & & & & & G Selt-concept \\
\hline Hay McBer (1996) & $\mathrm{V}$ & $\mathrm{V}$ & & $\mathrm{V}$ & $\mathrm{V}$ & V & $\mathrm{V}$ & V & & & \\
\hline Spencer \& Spencer (1993) & $\mathrm{V}$ & $\mathrm{V}$ & & $\mathrm{V}$ & $\mathrm{V}$ & $\sqrt{ }$ & & & & & I Ability \\
\hline Boyatzis (1982) & V & V & & v & V & & & $\sqrt{ }$ & & & J Expertise \\
\hline
\end{tabular}

Table 1 shows the breakdown of the elements of competence have been described by some researchers as the main features of competence. There are ten elements of competence which have been listed by nine researchers chosen. Ten elements of competence outlined by researchers are the knowledge, skills, attitudes, motives, traits, self-concept, self-worth, self-image, capabilities and expertise. Overall, most of the researchers said the main element of competence comprises of three components, namely knowledge, skills and attitudes. All three of these elements cannot be separated as to form teachers who really have a high level of competence to engage in education. Five researchers stated clearly that the elements of knowledge, skills and attitude are what determine an individual's level of competence at the level of either high, medium or low. They classify constructs motives, traits, self-worth, self-concept and self-image as a small fraction of elements attitude. Only Sinnott, Madison and Pataki (2002) stating that the element belongs capabilities and expertise as well as elements of competence than knowledge.

However, this competence element selection may also depend, as appropriate to the type of work involved researchers in the country. As for the teaching profession in Malaysia, has underlined that the elements of competence comprises knowledge, skills and personal characteristics (attitude) as contained in the Teacher Competency Standards Malaysia (Siraj \& Ibrahim, 2012). The concept paper will only discuss three elements of competence dealt with by the majority of researchers of knowledge, skills and attitudes to provide a clearer picture. Here discussed three elements:

\section{Knowledge}

Knowledge can be acquired by a teacher through reading books or reference materials on the internet site either in the form of text, image, video and so on. Knowledge is usually a form of words or statements. It is the awareness, information or understanding of the facts, rules, principles, 
concepts or processes necessary to perform a task and work (Hoge, Tondora \& Marrelli, 2005). General knowledge acquired through formal education, "on the job training" and experience. Knowledge can be broken down into general knowledge and knowledge of the discipline (Evers, Rush \& Berdrow, 1998). Knowledge is a fundamental problem that needs to be there in person teacher to implement teaching and learning, including practical FMP. Normally, knowledge, and there is a teacher in the form of theories. Science will increase from day to day if a teacher strives hardly to further improve the level of knowledge in himself. Aspects of knowledge that must be possessed by the teacher hands-FMP which is to understand the content of the lesson, learn the process of delivering educational, pedagogical and professional knowledge in the field of education.

If a teacher hands-FMP has a high theoretical knowledge but he is not skilled to treat its associates or those with elements of skill, it is a problem that must be corrected immediately. In other words if a teacher hands-FMP has only science but it is not adapted so it cannot be displayed in the form of practical internship. This led the students to feel tired every day if they just learn in theory in the field of FMP without being followed by practical sessions in the workshop. This of course cause them to look forward to learn and use machines and equipment available in the workshop to build or produce furniture with their own hands that can be used as guest knowledge and skills themselves.

\section{Skill}

Proficiency skill element is seen more geared to practical practice that will be on display from the knowledge that exists within a practical teacher FMP. A variety of skills that should be possessed by a teacher hands-FMP, which include skills teaching methods practical skills in using tools and machines practical skills of practical work and skills of using teaching aids during the practical sessions FMP done by students (Harun, 2014).

Practical teaching sessions in the workshop of course will be bland and dreary if a teacher does not have a hands-FMP high level of skill as he is unable to devote science skills at the proper level related hands-FMP to his students. It will simultaneously cause the pupils do not get proper supply of skills to bring to the stage of higher learning in the future. In addition, students may also be taught with methods or steps that do not work perfectly, insecurity and wrong. The security aspect must be emphasized by teachers hands-on practical sessions FMP along either inside or outside the workshop (Boon \& Ahmad, 2012).

\section{Attitude}

The attitude reflects an attitude of temperament and behaviour. According to Mohamed (2001), the behaviour is something that is always carried by an individual consciously or not. According to him, in the context of teaching and learning, attitude will be the main yardstick for determining whether the individual has been learning something new which is either positive or negative things. Attitudes can be formed, built and transformed through a process of effective teaching but it is a step that is difficult and requires a strong inner spirit and determination.

This is supported by Ariffin (2005), which states that there are two factors that influence the attitudes of internal and external factors. Internal factors refer to the passion and enthusiasm of someone who has close links to gender, ethnicity, financial resources and so on. While external 
factors also involve environmental conditions such as school facilities, workshop facilities, the categories of students, community support and so on.

According Marsom (2005), there are three components, namely behavioural attitudes, feelings and views but these components are difficult to distinguish from each other. According to him, the feeling can be changed from an excited state to a state that is not pleasant as grief and distress. Component behaviour is limited to behaviour favourable to harmful behaviour. While the component views or thoughts can change from thinking thoughts that are beneficial to nonbeneficial. Through attitude, humans can learn a variety of new knowledge to improve self-esteem and self-potential.

Baron (2008), also said that the three main components of the attitudes are cognitive, affective and behavioural. Cognitive is the individual opinion on something that involves the process of thinking, rationality, logical and confidence. This is supported by Mahmood Nazar Mohamed (2001), which describes the cognitive is an intellectual process that involves mental processes such as thinking, speaking, store information in memory and reuse the stored information to solve a problem when necessary

\section{Competency Model}

Competency model has been widely introduced by the character and competence of experts to explain more clearer related to the purposes, characteristics and components of competence in accordance with their respective studies. Two models of competence as a reference in this concept paper are:

\section{A) Working Competency Model Kanfer \& Ruth}

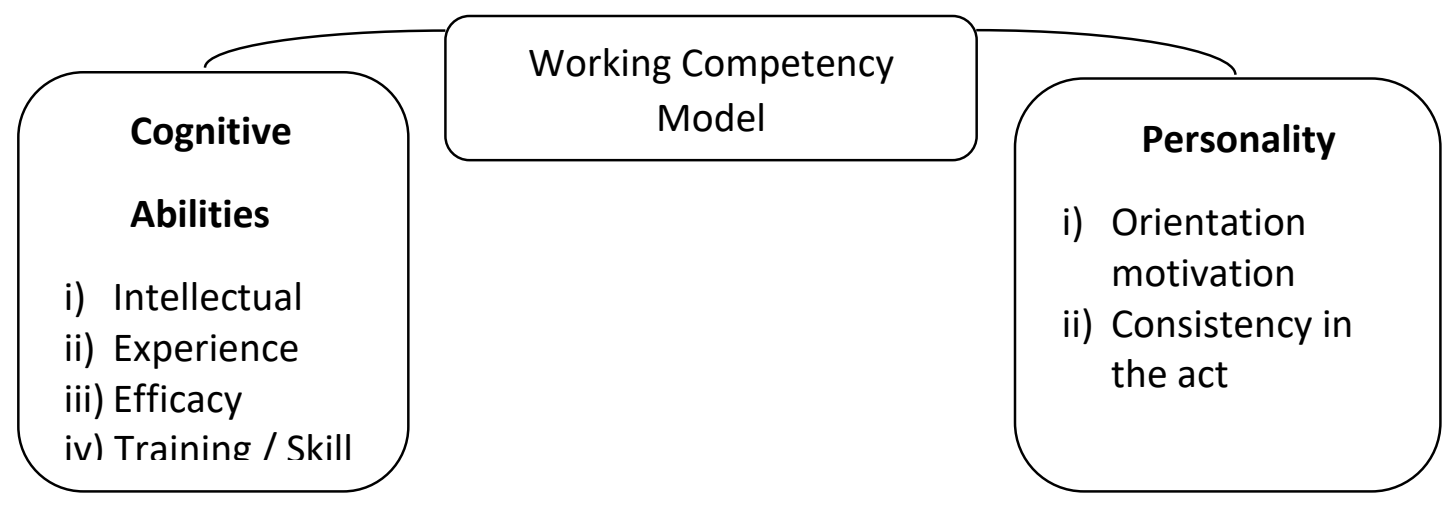

Figure1 Working Competency Model Kanfer \& Ruth (2005)

A competent workers affected by two main factors affecting the work of cognitive competence (cognitice abilities) and personality (personality). Cognitive abilities composed of intellectual (knowledge), experience, the efficacy and training (skills) while personality is divided into motivation and orientation consistently in the act (attitude). The personality of each individual is different and it will indirectly affect cognitive abilities factor in determining a person's job competence (Kanfer \& Ruth, 2005). 


\section{B) Iceberg Competency Model}

Iceberg Competency Model has been introduced by Spencer \& Spencer in 1993. Then it has been modified by Hay McBer in 1996 describing their skills and knowledge can often be obtained through training courses and may be associated with academic qualifications. While personal characteristics are characteristics present in an individual. Development of the personal characteristics of the worker is more challenging, and special emphasis should be given to achieve the desired success through training and personal development.

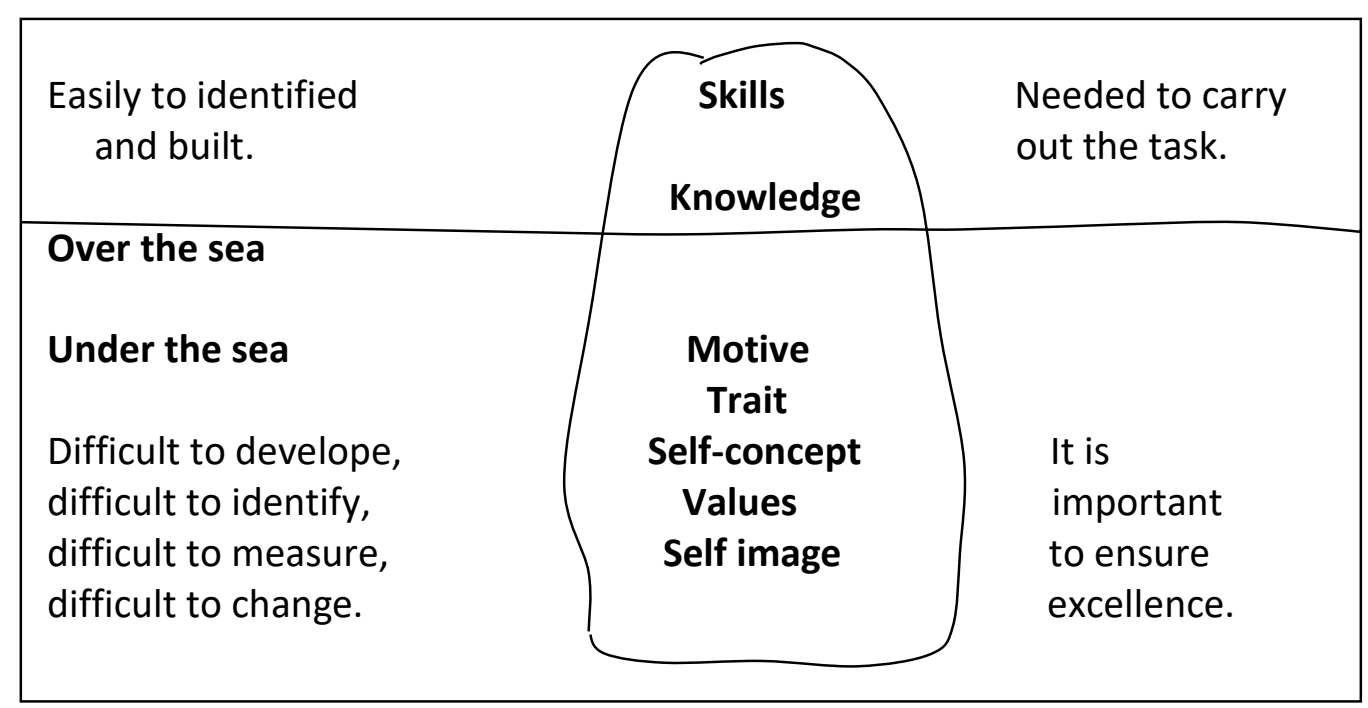

Based on Figure 2, competence is described as an ice cube or "iceberg" that is in the sea (Mohd Salim \& Jamalul Lail, 2016). Components of knowledge and skills is at the end of the iceberg is above the water level that is raised and can be seen with the naked eye. Both of these components are required to perform the duties and responsibilities as a teacher teaching practical FMP. While the components of personal attitude is also depicted below the water level that is hidden, difficult to identify, difficult to be developed and built tough. However, the attitude is more important component for determining the competence and excellence of a teacher than practical FMP component knowledge and skills. 
INTERNATIONAL JOURNAL OF ACADEMIC RESEARCH IN BUSINESS AND SOCIAL SCIENCES

Vol. 9, No. 5, May, 2019, E-ISSN: 2222-6990 @ 2019 HRMARS

Teacher Competency Framework Study Concept Furniture Manufacturing Practice

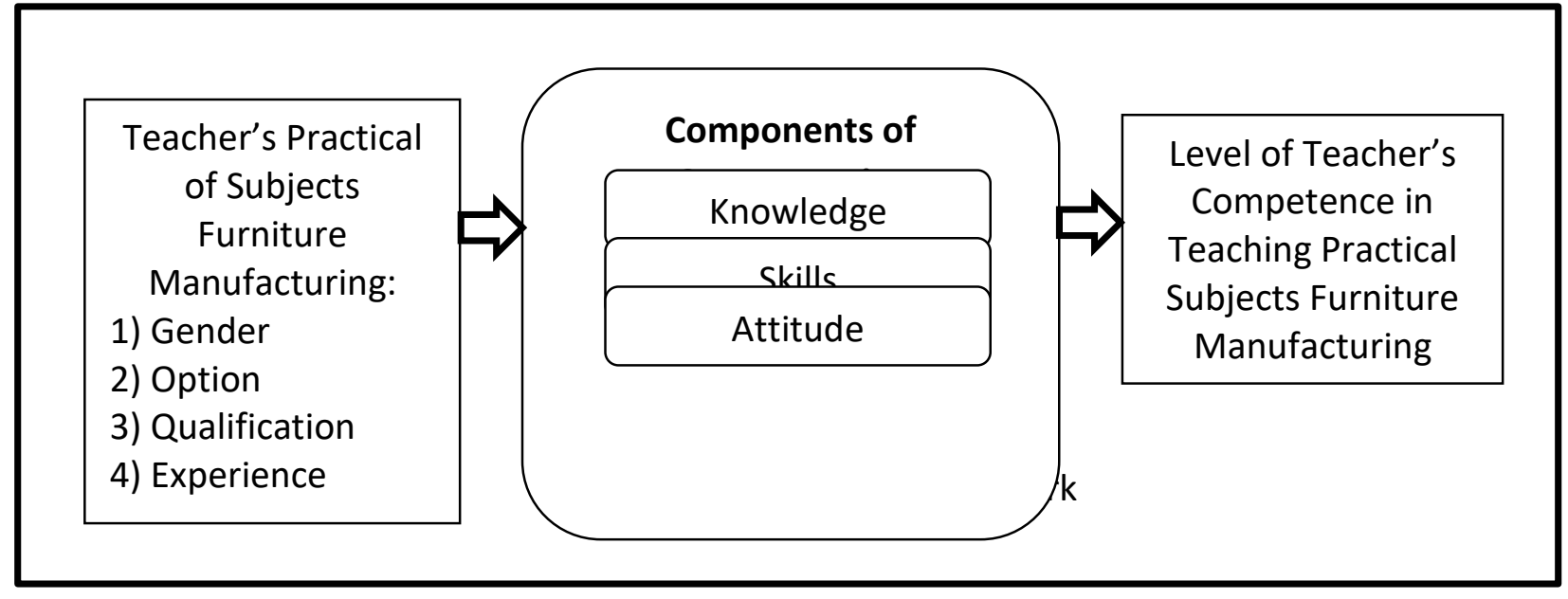

Figure 3 is a conceptual framework that describes the study of the relationship between subject teachers FMP with three components, namely competency components of knowledge, skills and attitude component parts. Components include teaching practical knowledge, learning objectives, content of learning and self-assessment of knowledge. For skills component consists of skill tools, machine tools and teaching, maintenance of machines and the teaching methods used by teachers. While the components of interest include teachers' attitudes towards teaching practice, teachers' appearance shown during the teaching and learning, teachers' responsibility as educators and teachers' confidence in teaching practice in the workshop.

\section{Issues of Competence of Teachers in Teaching Practical Fmp}

Official report from the World Bank and UNESCO-UNEVOC found teachers vocational training in developing countries, particularly in the South Asian region often does not meet the requirements of the working world that is facing a shortage of pedagogical skills to transfer knowledge and skills they have to disciples (Faridah et al., 2014). This is because there are some teachers who do not have the knowledge and skills that are in line with current developments in the industrialized world. There is a problem of competence among teachers hands-FMP include:

\section{A) Knowledge Teachers Are Owned Limited}

Every teacher should prepare themselves in advance with all the knowledge and skills related to preparation before engaging in Vocational Technical Education Program (Jamil \& Yahya, 2009). This is because the science related subjects adequate regulation is needed to become a vocational teacher. It includes practical knowledge of teaching, learning objectives, contents of learning and selfassessment of knowledge. Teachers who can educate and creative in delivering course content will make it easier for students to understand the concept or skill of a lesson, while teachers who otherwise are less competent teachers to teach students (Bakar, 2011). 
Knowledge and skills are lacking on the use of machine and engine maintenance work resulted in the learning process becomes less efficient and systematic. In addition to teaching and learning, management skills workshops also need to be considered by teachers to ensure the perfection of practical education (Minhat \& Hisyam, 2012). Low competence levels of teachers who would have posed a problem to students who attend hands-on learning sessions FMP in the shop.

\section{B) Lack of Conduct Practical Skills}

Teachers lack the skills to oversee the practical FMP will face practical problems to handle with care. If teachers cannot control well the practical sessions students will have a problem because they cannot learn the skills based on modules that have been set by the Curriculum Development Division (CDD) perfectly. Aspects of the skills that must be possessed by teachers teaching practical skills FMP is made up of the use of hand tools, mechanization and teaching equipment, machine maintenance and teaching methods suitable for practical use by teachers involved. Oriented teaching internship in the workshop or laboratory skills teachers need to ensure that the maximum science skills that served really good quality and conform to standard practice ( Bakar, Hamzah \& Udin, 2011).

It's very different to teaching academic subjects in theory only be implemented in the classroom. During practical lessons FMP, teachers need to be together in the workshop for students demonstrating and monitoring the movements and workings of the students using the machines and equipment in order to protect and ensure the safety of students. Reproof and correction must be carried out immediately if there are students who make mistakes in work steps and methods of use of tools and machinery. Teachers are less or medium level skills will be faced with a conflict to handle practical sessions PP with good, orderly and safe.

\section{C) Negative Attitude of The Teacher}

Personal negative aspects embedded in a person will also become a stumbling block to a teacher to achieve excellence in the teaching profession. This is because there is one teacher who has the knowledge and skills but weak in terms of value (attitude). According to a study conducted by Osman (2014) found that the level of competence of female teachers in Perak State Vocational College in handling practical aspects of knowledge and skills are in the medium level but aspects of attitude is in low level. This is a situation that must be dealt with promptly by all parties concerned either by the ministry, the administration nor the teachers as. If allowed to persist such things happen then it will certainly have an adverse impact on all parties, particularly to their pupils.

In addition, when a teacher is unable to control and workshop management duties properly then there will be problems such as equipment and machinery in the workshop will be quickly damaged by poorly maintained or not according to the scheduled maintenance. The costs of machinery and equipment will also be increased when these problems occur because of the damage is likely to be small initially spread to worse (Ali et. al, 1996). This will cause the tool cannot be used and is not enough to be used by students to do practical work. Most likely to occur accidents will also increase when the machine is not maintained properly by limitation period of time determined by its manufacturer. This of course would pose a danger to students and teachers in particular, itself generally. It is the negative attitude that must be eradicated from existence within a teacher who handle practical FMP. Bad attitude will be observed indirectly but may be followed by students in one 
INTERNATIONAL JOURNAL OF ACADEMIC RESEARCH IN BUSINESS AND SOCIAL SCIENCES

Vol. 9, No. 5, May, 2019, E-ISSN: 2222-6990 @ 2019 HRMARS

day. It is the negative attitude that must be eradicated from existence within a teacher who handle practical FMP. Bad attitude will be observed indirectly but may be followed by students in one day. It is the negative attitude that must be eradicated from existence within a teacher who handle practical FMP. Bad attitude will be observed indirectly but may be followed by students in one day.

\section{Conclusion}

Teachers' competent in carrying out their teaching practical subjects regulation is urgently needed to meet the National Education Philosophy (NEP) who wants to pupils integrated in selected developed produce a balanced and harmonious. The technical and vocational teachers nowadays need to equip themselves with the skills to cope with globalization in education. The government has taken various initiatives to improve the skills and knowledge of teachers through teacher training programs introduced. It aims to realize the National Educational Goals and Vision 2020 to make teachers always excelled in the teaching profession.

However, the business is highly dependent on the actions of teachers practical initiatives FMP myself that equip themselves with knowledge and skills in line with the demands of professional colleges in addition to inculcate and admirable character. As an educator who is responsible, teachers involved must be aware of the duties and responsibilities of educating the current generation of adults will be useful in the future to religion, race and country.

\section{Acknowledgement}

This paper is founded on the master research project of the Competence of Instructor in Practicing Teaching of Furniture Manufacturing in Malaysia. Special appreciation is owed to my supervisor and family for sponsoring and supporting this research.

\section{Corresponding Author}

Mohd Zaini Osman, Faculty of Technic and Vocational, Universiti Pendidikan Sultan Idris, 35900 Tanjung Malim, Perak, Malaysia

E-mail: mohdzainiosman76@gmail.com

\section{References}

Bakar, A. M. H. (2011). “Cabaran Memperkasakan Pendidikan Teknik Dan Vokasional.” Prosiding Penyelidikan TVET Peringkat Negeri.

Ali, H., Md Aris, S. \& Ayob, M. M. (1996). Teknologi Penyejukan Dan Penyaman Udara. Kuala Lumpur: Edusystem Sdn Bhd.

Bloom, B. S. (1956). Taxonomy of Educational Objectives, the Classification of Educational Goals Handbook I: Cognitive Domain. New York: McKay.

Boyatzis, Richard, E. (1982). The Competent Manager: A Model for Effective Performance. New York, NY: John Wiley \& Sons.

Cachia R, Ferrari A, Ala-Mutka K, Punie, Y. (2010). Creative Learning and Innovative Teaching. JRC Scientific and Thechnical Reports.

Carraciao, C. \& Englander, R. (2004). Understanding Competency-Based Education. London: Routlegde Inc. 
INTERNATIONAL JOURNAL OF ACADEMIC RESEARCH IN BUSINESS AND SOCIAL SCIENCES Vol. 9, No. 5, May, 2019, E-ISSN: 2222-6990 @ 2019 HRMARS

Ibrahim, D. 2003. “Mengenalpasti Masalah-Masalah Dalam Melaksanakan Standard ISO 9000.” UKM, BANGI.

Evers, Rush, Berdrow. (1998). The Bases of Competence: Skills for Lifelong Learning and Employability. Jossey-Bass.

Greenberg, J. \& Baron, R.A. (2008). Behavior in Organization. Edited by Prentice Hall. 10th Edition. New Jersey.

Hoge, Tondora, Marrelli. (2005). "The Fundamentals of Workforce Competency: Implications for Behavioral Health."

Baser, A. J. \& Bunta, Y. (2009). “Pembelajaran Informal Bagi Guru Mata Pelajaran Teknologi Kejuruteraan," 1-10.

Kanfer \& Ruth, P. (2005). "Work Competence: A Person Oriented Perspective." In Handbook of Competence and Motivation., edited by Andrew J. Elliot, 336-53. New York: The Guilford Press.

Mohamed, M. N. (2001). Penghantar Psikologi Satu Pengenalan Asas Jiwa Kepada Jiwa Dan Tingkahlaku Manusia. Kuala Lumpur: Dewan Bahasa Dan Pustaka.

Marsom, S. (2005). “Keperluan Pelajar Pendidikan Teknik Dan Vokasional Dalam Menjalani Latihan Industri." Kuithho:

Mestry, R., Grobler, B. R. (2004). "The Training and Development of Principals to Manage Schools Effectively Using the Competence Approach." International Studies in Educational Administration 32 (3): 2-19.

Aderemy, M. \& Hashim, M. H. M. (2012). “Persepsi Guru-Guru Bidang Teknik Dan Vokasional Sekolah Menengah Kebangsaan Tinggi Segamat Dalam Meningkatkan Kecerdasan Emosi Pelajar: Satu Kajian Kes Kualitatif." Prosiding Seminar Pendidikan Pasca ljazah Dalam PTV Kali $\mathrm{Ke}-2,2012,1-17$.

Awang, M. S. \& Wahab, J. L. A. (2016). “Guru Dalam Pengurusan Kokurikulum Dan Salah Laku Pelajar." ICERD 2016, Bandung, Indonesia, 1-8.

N, N. A. B., Hamzah, R. \& Udin, A. (2011). "Cabaran-Cabaran Dalam Pendidikan Teknik Dan Vokasional Dalam Membangunkan Sumber Manusia." Journal Of Edupres Volume 1 (September 2011): 159-64.

Osman, N. J. (2014). “Kompetensi Guru Wanita Dalam Melaksanakan Kerja Amali Di Kolej Vokasional Negeri Perak." Universiti Tun Hussein Onn.

Ariffin, N. (2005). “Persepsi Pelajar Terhadap Sikap, Pengetahuan Dan Kemahiran Dalam Mata Pelajaran Vokasional Di Sekolah Menengah Akademik Di Batu Pahat. Projek Sarjana."

Rylatt, A. \& Lohan, K. (1995). Creating Training Miracles. 350 Sansome Street, 5th Floor, Sydney, San Francisco: Prentice-Hall.

Siraj, S., \& Ibrahim, M. S. (2012). "Standard Kompetensi Guru Malaysia," 1-44.

Sinnott, G. C., Madison G. H. \& Pataki, G. E. (2002). "Competencies: Report of the Competencies Workgroup", September: 1-47. papers2://publication/uuid/DFA21E20-5A15-4A3B-A3EAFF1904720329.

Boon, Y., \& Ahmad, A. I. (2012). “Amalan Keselamatan Bengkel Dalam Kalangan Guru-Guru Pelatih 4 SPH (Sarjana Muda Teknologi Serta Pendidikan Kemahiran Hidup) Semasa Mengikuti Latihan Mengajar Di Sekolah." Journal of Technical, Vocational \& Engineering Education, Volume 6: 102-14. 
INTERNATIONAL JOURNAL OF ACADEMIC RESEARCH IN BUSINESS AND SOCIAL SCIENCES

Vol. 9, No. 5, May, 2019, E-ISSN: 2222-6990 @ 2019 HRMARS

Harun, Z. N. Md. (2014). “Kompetensi Guru Dalam Pengajaran Amali RekaBentuk Dan Teknologi Di Sekolah Rendah Daerah Batu Pahat." UTHM. 